Article

\title{
Large Day-to-Day Variability of Extreme Air Temperatures in Poland and Its Dependency on Atmospheric Circulation
}

\author{
Katarzyna Szyga-Pluta
}

Citation: Szyga-Pluta, K. Large Day-to-Day Variability of Extreme Air Temperatures in Poland and Its Dependency on Atmospheric Circulation. Atmosphere 2021, 12, 80. https://doi.org/10.3390/ atmos12010080

Received: 15 December 2020 Accepted: 31 December 2020 Published: 7 January 2021

Publisher's Note: MDPI stays neutral with regard to jurisdictional clai$\mathrm{ms}$ in published maps and institutional affiliations.

Copyright: (C) 2021 by the author. Licensee MDPI, Basel, Switzerland. This article is an open access article distributed under the terms and conditions of the Creative Commons Attribution (CC BY) license (https:// creativecommons.org/licenses/by/ $4.0 /)$.
Department of Meteorology and Climatology, Adam Mickiewicz University in Poznań, ul. Krygowskiego 10, 61-680 Poznań, Poland; pluta@amu.edu.pl

\begin{abstract}
The primary purpose of the study was the determination of the spatial day-to-day variability of extreme air temperatures in Poland and the dependency of large temperature changes on atmospheric circulation in accordance with the Grosswetterlagen (GWL) classification. The goal was achieved based on data from 1966 to 2015, made available by the Institute of Meteorology and Water Management-National Research Institute. Day-to-day changes in maximum and minimum air temperatures were designated with a rate of $\geq 6{ }^{\circ} \mathrm{C}$ (large) and with a rate of $\geq 12{ }^{\circ} \mathrm{C}$ (very large) and their spatial distribution was presented. Finally, the analysis of the dependency of considerable temperature changes on atmospheric circulation in accordance with the Grosswetterlagen (GWL) classification was conducted. The obtained results showed that in Poland in the period 1966-2015 there was a statistically significant increase in the number of large changes in both Tmax and Tmin. The number of large changes in Tmax increases from north to south, and the number of large changes in Tmin from north to east and south of Poland indicate the range of the effect of marine and continental properties on the climate of Poland and the influence of local relief as well as the atmospheric circulation impact. Large changes in Tmax occur more frequently in spring and in Tmin in winter. Large changes in Tmax and Tmin are mainly recorded during cyclonic circulation, however, the anticyclonic circulation types favour especially large decreases in Tmin.
\end{abstract}

Keywords: air temperature extremes; day-to-day variability; large changes; circulation types; Grosswetterlagen; Poland

\section{Introduction}

The observed contemporary climate warming is visible in the increase of the average global air temperature [1]. In the majority of cases, changes in mean daily air temperature are relatively low and rarely interrupted with high temperature increases [2]. Together with climate change, the values of minimum and maximum temperatures also increase. These result in day-to-day variability of maximum and minimum air temperatures. It is also worth emphasizing that variations in minimum temperatures are usually greater than those in maximum temperatures [3,4]. The variability of such changes in a year is probably uneven. Air temperature is largely generated by circulation factors [2,5]. The greatest day-to-day changes in temperature are related to the North Atlantic Oscillation (NAO). The intense NAO is related to the lowest minimum temperature in winter, spring and over the whole year, and the highest maximum temperature is higher than usual in autumn and winter during the years in which the NAO was strong [6]. Notwithstanding this, higher values of the NAO index are usually related not only to higher temperatures but also to lower day-to-day variability [3]. It was pointed out that extreme values of air temperature are associated with anticyclonic circulation and strong highs blocking the zonal circulation, which in recent decades have been increasingly occurring over Europe, and are of particular importance [7-9].

Analyses of trends in the period 1880-1998 [10] show that the variability of the spatial distribution of day-to-day temperature changes was subject to the following changes: a 5\% 
increase occurred in south-western Europe, a change of 0 to $-5 \%$ in the north-west, and a decrease by 5 to $10 \%$ in north-eastern Europe. Very large day-to-day changes in temperature are forecasted to occur increasingly frequently in summer [11]. The effects of climate change can depend more on the change in the minimum (Tmin) or maximum air temperature (Tmax) than mean temperature [12]. Otherwise, the effect of precipitation deficit on an increase in extreme values of daily temperature amplitude has been observed [13]. Studies of temperature and cloud cover indicate a strong relationship of a temperature increase in Europe with a decrease in cloudiness [14]. In addition, several studies showed the dependence of mid-latitude cloud radiative properties on temperature e.g., $[15,16]$. Clouds and aerosols continue to contribute the largest uncertainty to estimates and interpretations of the Earth's changing energy budget [17]. The changes of atmospheric circulation in Europe during 1981-2014 were accompanied generally by a reduction of the total cloud cover over the continent, and this leads to an overall increase of the shortwave incoming radiation at continental scale causing a possible increase of air temperature [18].

Day-to-day temperature variability is of significance not only as an important characteristic of climate dynamics. Changes in mean daily temperature are on average lower than those in the case of extreme air temperatures $[19,20]$. The decrease in the diurnal temperature range is approximately equal to the increase in mean temperature [21]. It is also interesting from a practical point of view. Substantial temperature fluctuations are unfavourable for the well-being of man, showing an irritating effect [22], and can have a negative impact on many areas of the economy, e.g., rapid cooling in spring can cause freeze damage of plants, and rapid warming can lead to fast snowmelt resulting in flood threat [22-25].

Fewer studies in the climatological literature are devoted to the day-to-day variability of maximum and/or minimum air temperature e.g., [6,20,26-31] compared to the number of studies concerning the mean temperature interdiurnal variations (ITV) or diurnal temperature range (DTR) e.g., [3,10,11,25,32,33]. Additionally, the occurrence and changes of extreme air temperature values should be discussed in the context of circulation conditions, because atmospheric circulation is considered one of the most important factors influencing weather and climate conditions in mean latitudes [34,35].

Bearing the aforementioned in mind, the knowledge of the probability and conditions of occurrence of considerable temperature changes are of particular importance, especially in the case of the impact on human well-being and the economy. The main objective of the research was the determination of the spatial day-to-day variability of extreme air temperatures in Poland and its circulation conditions. The implementation of the primary study objective covers the determination of the spatial and multiannual variability of changes in extreme air temperature: maximum (Tmax) and minimum (Tmin) from day to day in the period 1966-2015, and the designation of cases of large $\left(\geq 6^{\circ} \mathrm{C}\right)$ and very large $\left(\geq 12{ }^{\circ} \mathrm{C}\right)$ increases and decreases in extreme temperatures in particular months, years, and throughout the multiannual period. Particular attention was paid to the analysis of the impact of atmospheric circulation on the occurrence of large changes in extreme air temperature (Tmax and Tmin).

\section{Materials and Methods}

The analysis was based on meteorological data from 24 stations in Poland (Figure 1) belonging to the observation network of the Institute of Meteorology and Water ManagementNational Research Institute (IMGW-PIB). The analysis covered the period 1966-2015.

The calculations were based on daily values of maximum and minimum air temperature. A day-to-day change in maximum temperature $(\Delta T \max )$ was calculated as the difference between maximum temperature on a given day and the preceding day. A day-today change in minimum temperature was determined analogically $(\Delta \mathrm{Tmin})$. The absolute values of the changes were taken into account when calculating the mean annual day-to-day changes. Day-to-day changes in maximum and minimum air temperatures were designated with a rate of $\geq 6{ }^{\circ} \mathrm{C}$, in the paper described as large, and those with a rate of $\geq 12{ }^{\circ} \mathrm{C}$, 
described as very large. These thresholds are considered for the area of Poland as having a negative impact on people [22]. Day-to-day changes in air temperature of more than $6^{\circ} \mathrm{C}$ have an irritating effect on the human organism (classification by Bajbakova et al. [22]), and changes of more than $12{ }^{\circ} \mathrm{C}$ are described as severe [22]. The number of positive and negative changes were determined for $\operatorname{Tmax}(\Delta \operatorname{Tmax} \uparrow, \Delta \operatorname{Tmax} \downarrow)$ and $\operatorname{Tm} \min (\operatorname{Tm} \min \uparrow$, $\operatorname{Tmin} \downarrow$ ), as well as their occurrence in particular months and years in the analysed period. Trends of multiannual changes in temperature increases and decreases were determined, as well as their statistical significance. The determination of the trend of values averaged for the territory of Poland employed a 5-day moving average. The statistical assessment of changes applied a nonparametric Mann-Kendall test, and their statistical significance was assessed by means of the Sen method [36]. The spatial distribution of large changes in extreme air temperatures was presented in maps.

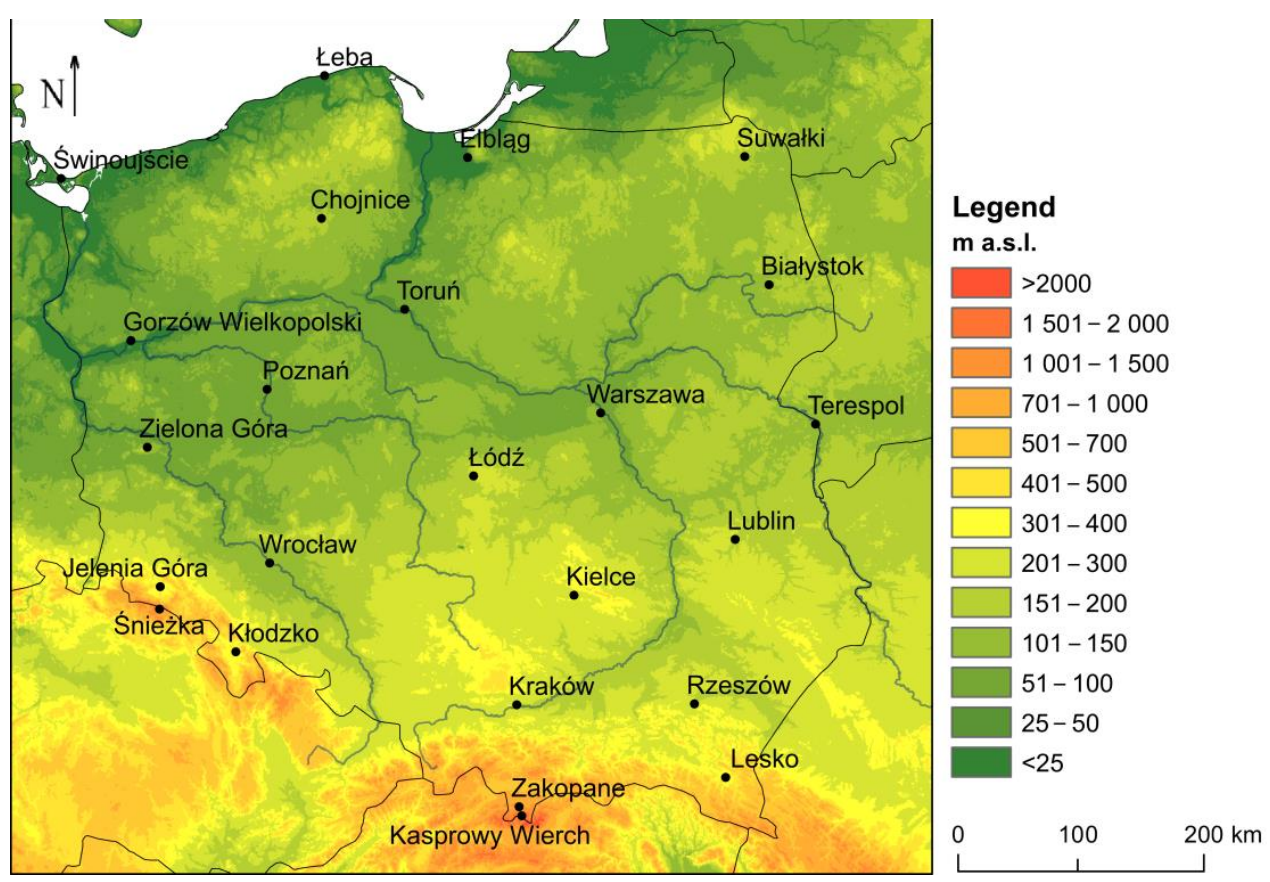

Figure 1. Locations of the analysed stations in Poland.

The next stage involved the analysis of the dependency of considerable temperature changes on the atmospheric circulation in accordance with the Grosswetterlagen (GWL) classification [37] (Table 1). The "Grosswetterlagen" focuses on similar atmospheric processes in a larger area, e.g., Europe. The first calendar of European Grosswetterlagen comprised 21 GWL. Baur's initial concept was further developed and extended to $29 \mathrm{GWL}$ in the following decades by Hess and Brezowsky [38], therefore, it is also known under their name. Later updates were published by Gerstengarbe and Werner [39]. Its development involved the use of surface synoptic maps and geopotential height charts at the $500 \mathrm{hPa}$ level, with consideration of direction of air flow and location of pressure systems. A total of 30 circulation types were distinguished and additionally grouped in Grosswettertypen (GWT) by air mass advection [39]. The objective method for classifying synoptic weather regimes over Europe and the North East Atlantic, based closely on the widely used Grosswetterlagen (GWL) series of Hess and Brezowsky, was constructed by James [37], in which a pattern correlation technique is used to find the best matching types from a set of pre-defined patterns representing the respective GWLs. 
Table 1. Definitions of the circulation types (GWT) and the atmospheric circulation patterns (GWL) [37].

\begin{tabular}{|c|c|c|}
\hline Circulation Type (Grosswettertype; GWT) & Symbol & Atmospheric Circulation Patterns (Grosswetterlage; GWL) \\
\hline \multirow{6}{*}{ North } & $\mathrm{HB}$ & British Isles High \\
\hline & HNA & Norwegian Sea High, anticyclonic \\
\hline & HNZ & Norwegian Sea High, cyclonic \\
\hline & NA & North Circulation, anticyclonic \\
\hline & NZ & North Circulation, cyclonic \\
\hline & TRM & Central Europe Trough \\
\hline \multirow{2}{*}{ Northeast } & NEA & Northeast Circulation, anticyclonic \\
\hline & NEZ & Northeast Circulation, cyclonic \\
\hline \multirow{4}{*}{ East } & HFA & Fennoscandian High, anticyclonic \\
\hline & HFZ & Fennoscandian High, cyclonic \\
\hline & HNFA & Norwegian Sea/Fennoscandia High, anticyclonic \\
\hline & HNFZ & Norwegian Sea/Fennoscandia High, cyclonic \\
\hline \multirow{2}{*}{ Southeast } & SEA & Southeast Circulation, anticyclonic \\
\hline & SEZ & Southeast Circulation, cyclonic \\
\hline \multirow{4}{*}{ South } & SA & South Circulation, anticyclonic \\
\hline & $\mathrm{SZ}$ & South Circulation, cyclonic \\
\hline & TB & British Isles Low \\
\hline & TRW & Western Europe Trough \\
\hline \multirow{2}{*}{ Southwest } & SWA & Southwest Circulation, anticyclonic \\
\hline & SWZ & Southwest Circulation, cyclonic \\
\hline \multirow{4}{*}{ West } & WA & West Circulation, anticyclonic \\
\hline & WS & West Circulation, cyclonic \\
\hline & WZ & Southern West Circulation \\
\hline & WW & Angled West Circulation \\
\hline \multirow{2}{*}{ Northwest } & NWA & Northwest Circulation, anticyclonic \\
\hline & NWZ & Northwest Circulation, cyclonic \\
\hline \multirow{2}{*}{ Central Europe High } & $\mathrm{HM}$ & Central European High \\
\hline & $\mathrm{BM}$ & Central European Ridge \\
\hline \multirow[t]{2}{*}{ Central Europe Low } & $\mathrm{TM}$ & Central European Low \\
\hline & $\mathrm{U}$ & Undefined \\
\hline
\end{tabular}

Since such circulation biases are hard to assimilate easily when 29 types are used, the GWLs were concatenated into a small set of basic circulation types representing westerly, northerly, easterly, southerly, central, and cyclonic or anticyclonic circulation types, respectively (Table 2). Mixed types are grouped into both adjacent circulation types with half-weighting, respectively (e.g., northerly and westerly in the case of NWZ). In all cases, the circulation type definition is based on the character of circulation over Central Europe [37]. Developed for central Europe (Germany), the GWL concept works well for a much larger region, covering all of Europe [40]. The typology has been used in numerous papers investigating Central Europe [23,41-47].

Table 2. Definition of the circulation types and their associated atmospheric circulation patterns.

\begin{tabular}{|c|c|c|}
\hline \multirow{2}{*}{$\begin{array}{c}\text { Circulation } \\
\text { Type }\end{array}$} & \multicolumn{2}{|l|}{ Associated Grosswetterlagen } \\
\hline & Full Weight & Half Weight \\
\hline Westerly & WA, WZ, WS, WW & SWA, SWZ, NWA, NWZ \\
\hline Northerly & NA, NZ, HNA, HNZ, HB, TRM & NWA, NWZ, NEA, NEZ \\
\hline Easterly & HFA, HFZ, HNFA, HNFZ & SEA, SEZ, NEA, NEZ \\
\hline Southerly & SA, SZ, TB, TRW & SWA, SWZ, SEA, SEZ \\
\hline Central & $\mathrm{HM}, \mathrm{BM}, \mathrm{TM}$ & \\
\hline Cyclonic & WZ, WS, WW, SWZ, NWZ, TM, NZ, HNZ, TRM, NEZ, HFZ, HNFZ, SEZ, SZ, TB, TRW & \\
\hline Anticyclonic & WA, SWA, NWA, HM, BM, NA, HNA, HB, NEA, HFA, HNFA, SEA, SA & \\
\hline
\end{tabular}


In this research, to eliminate individual cases occurring in the few stations, only these cases were analysed when large changes in extreme air temperature values occurred at least in $20 \%$ of the stations. The frequency of occurrence of GWL circulation types in the years 1966-2015 was calculated, as well as the probability of occurrence of large day-today changes in Tmax and Tmin in particular atmospheric circulation patterns (GWL) of particular circulation types (GWT).

\section{Results}

\subsection{Mean Annual Day-to-Day Changes of Tmax and Tmin}

In the analysed period 1966-2015, the mean annual absolute values of the day-to-day changes in Tmax and Tmin in Poland were $2.3{ }^{\circ} \mathrm{C}$ and $2.5^{\circ} \mathrm{C}$, respectively, and showed spatial variability (Figure 2). Mean day-to-day changes in Tmax increased from the north to the south of the country and ranged from $2.1^{\circ} \mathrm{C}$ in the Baltic Sea coast (Łeba, Świnoujście), to $2.7^{\circ} \mathrm{C}$ at the foothill of Tatra Mountains (Zakopane). In the coastal region, day-to-day air temperature changes are the least considerable as a manifestation of the mitigating effect of the sea on the climate, as confirmed by earlier studies [27]. Mean absolute changes in Tmin were lowest in the western part of Poland and increased south- and eastwards generally except for the central-eastern area, which is characterised by rather lower values. They varied from $2.0^{\circ} \mathrm{C}$ in the western parts of the Polish coastline (Świnoujście) and Wielkopolska Lowland (Zielona Góra) to $3.2^{\circ} \mathrm{C}$ in the valley at the foot of the Sudetes (Jelenia Góra). The higher day-to-day variability in east than in the west of Poland is due to the maritime and continental air masses range influence, which manifests itself in increasing thermal continentalism towards the east of the country. According to KossowskaCezak [19], a very rapid change in thermal conditions in the lowland area of Poland is caused by the advection of air masses and the inflow of air from over a thermally contrasting surface. The high values of day-to-day changes at the foothills are due the effect of the mountain ranges causing the local air circulation.

Mean absolute day-to-day change in Tmax in Poland was the most considerable in 1983 , reaching $2.5^{\circ} \mathrm{C}$, and the lowest in 1974 , reaching $2.0^{\circ} \mathrm{C}$. In the analysed multiannual period, the highest number of stations with the highest mean day-to-day change in Tmax, i.e., 10 out of 24 of the analysed stations, was recorded in 1983. Nineteen-seventy-four and 2005 were the years with the highest number of stations ( 5 out of 24 stations) with the lowest mean day-to-day change in Tmax.

Mean absolute day-to-day change in Tmin in Poland was the highest in 2012, reaching $3.2{ }^{\circ} \mathrm{C}$, and the lowest, reaching $2.2^{\circ} \mathrm{C}$, in 1972. In 1987, the highest number of stations was characterised by the highest mean day-to-day change in Tmax- 5 out of 24 stations. The lowest mean of the discussed changes in Tmin occurred in 1974 (8 stations out of 24).

In the years 1966-2015, the number of considerable changes in both Tmax and Tmin increased in Poland, although the variability shows spatial differentiation, and the changes are statistically significant only in some of the stations. Mean changes for the entire country showed a statistically significant increase in changes in extreme temperatures at a level of 0.001 (Figure 3). 


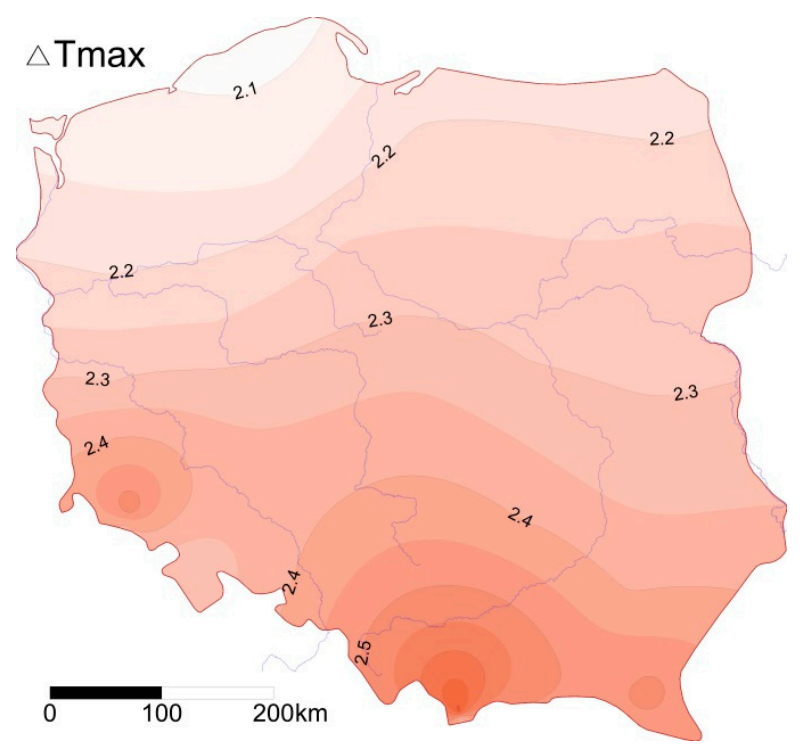

(a)

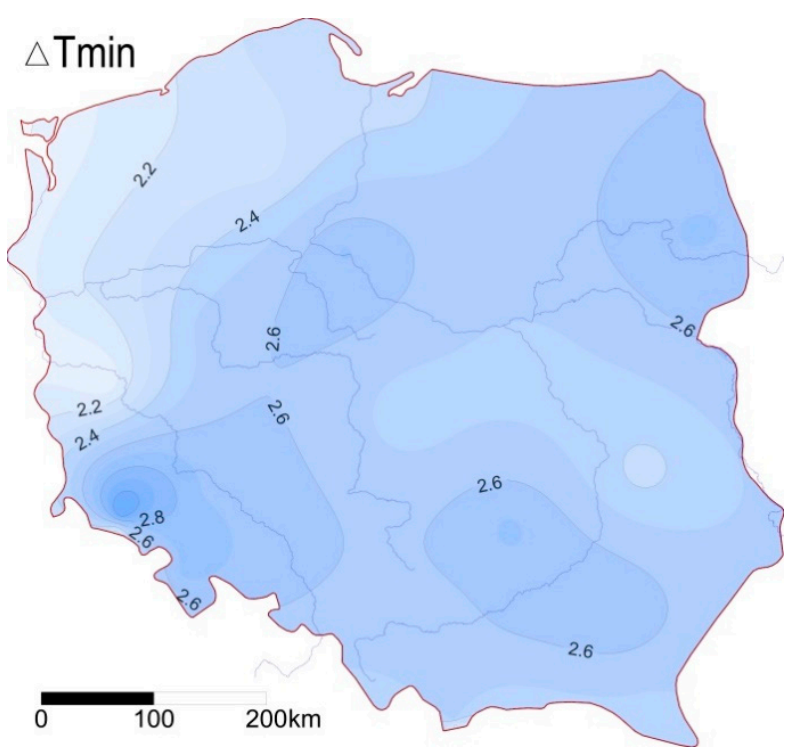

(b)

Figure 2. Average annual day-to-day changes of Tmax (a) and Tmin (b) in Poland in the years 1966-2015.

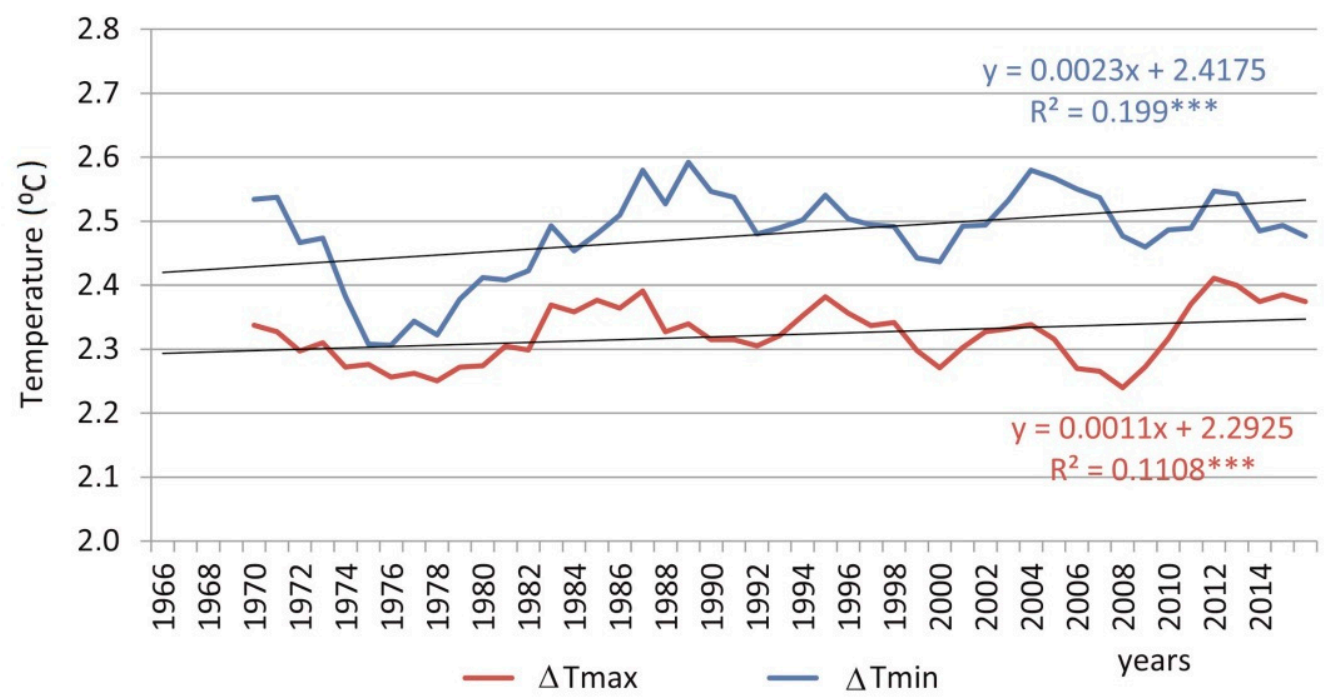

Figure 3. Fluctuation of 5-year moving mean of day-by-day Tmax and Tmin changes in Poland in the years 1966-2015. (Explanation: ${ }^{* * *} p<0.001$ ).

Most of the analysed stations (16 out of 24) showed a mean absolute changes increase in both Tmax and Tmin (Figure 4). A similar trend of changes was earlier found in northeastern Poland - the direction of trends in the analysed stations was variable as Panfil [28] stated. However, only in Warsaw $(p<0.05)$, Świnoujście and Białystok $(p<0.1)$ this trend is statistically significant in the case of Tmax. Similarly, according to previous research [29], trends of multiannual changes in Olsztyn showed statistically significant increases and decreases only for Tmax. In the case of Tmin, a statistically significant increasing trend is typical mainly in the center of the country, e.g., Łódź $(p<0.01)$ and Terespol $(p<0.001)$ in the eastern part. In the Carpathian foothills, a decrease in these changes in the range of Tmax and Tmin are observed e.g., Lesko. In turn, a few stations, e.g., Torun, are characterised by a negative tendency of changes in Tmax and positive in Tmin $(p<0.01)$. 


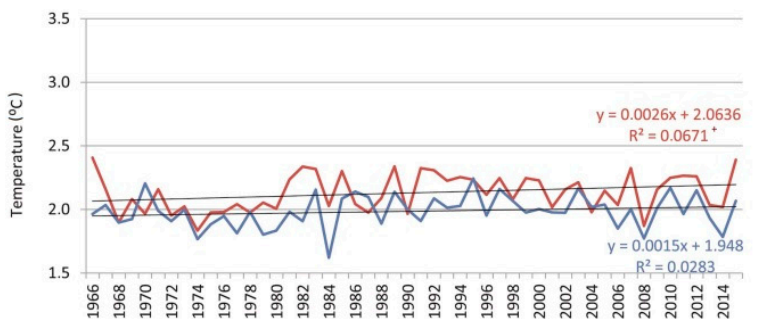

Świnoujście

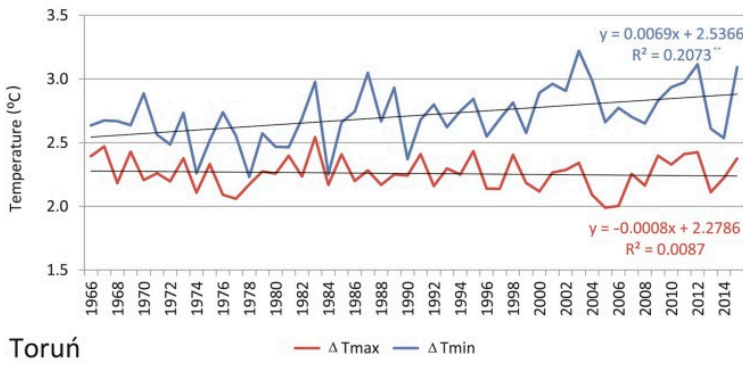

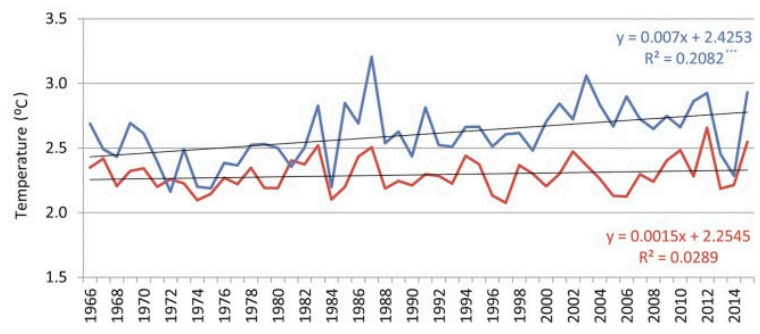

Terespol $\quad-\Delta$ Tmax $-\Delta$ Tmin

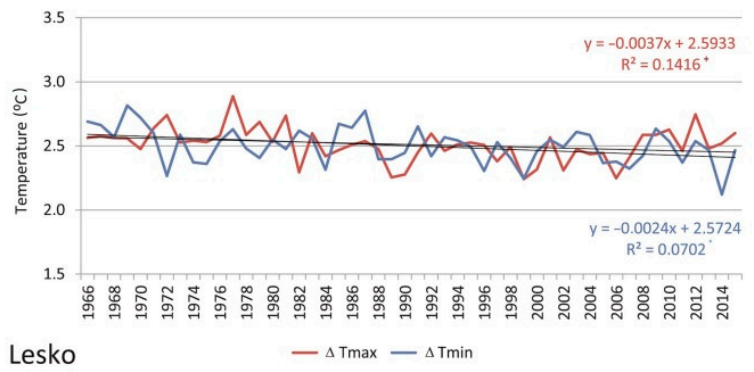

Figure 4. Annual mean day-by-day $\Delta \mathrm{Tmax}$ and $\Delta \mathrm{Tmin}$ course in selected stations in Poland in the years 1966-2015 with the trend lines (Explanations: $+p<0.1 ;{ }^{*} p<0.05 ;{ }^{* *} p<0.01 ;{ }^{* * *} p<0.001$ )

In the major area of the territory of Poland, based on this research, higher ranges of large changes in maximum than minimum air temperatures were recorded. According to previous studies, less increases in Tmax exceeding 10 degrees than Tmin were recorded in north-eastern Poland, but in the case of decreases, the number is approximate [28]. As Ciaranek [30] indicated, the rapid changes of Tmax $\left(\geq 10^{\circ} \mathrm{C}\right)$ in winter occurred in Poland more frequently in the first half of the analysed period 1961-2010. Therefore, according to this research [30], if this tendency of changes is maintained, a decrease in the frequency of occurrence of rapid changes in maximum air temperature can be expected in the following years in Poland in the cold season.

\subsection{Large Day-to-Day Changes of Tmax and Tmin}

The total annual number of large day-to-day changes in maximum air temperature in the analysed stations in Poland in the research period is 483 cases with $\Delta \operatorname{Tmax} \geq 6{ }^{\circ} \mathrm{C}$. The number varied in particular stations from 16 cases/year in Chojnice and Gorzów Wielkopolski to 30 cases/year in Zakopane. In the discussed period in the above mentioned number, just an average of nine cases of $\Delta \operatorname{Tmax} \geq 12{ }^{\circ} \mathrm{C}$ occurred annually, from 0.2 cases/year in Gorzów Wielkopolski to 0.8 cases/year in Świnoujście.

The total number of large interdiurnal changes in minimum air temperature $\left(\Delta \operatorname{Tmin} \geq 6{ }^{\circ} \mathrm{C}\right)$ in the selected stations in Poland in the analysed period averaged 631 cases annually, varying from 9 in Świnoujście to 54 in Jelenia Góra. Very large changes in minimum temperature $\left(\Delta \operatorname{Tmin} \geq 12^{\circ} \mathrm{C}\right)$ in Poland occurred on average 20 times in a year in the period 1966-2015-from 0.1 cases in Gorzów Wielkopolski and Zielona Góra to 3.7 in Jelenia Góra.

In the years 1966-2015, the average annual number of cases of increases in large changes in $\operatorname{Tmax}\left(\Delta \operatorname{Tmax} \uparrow \geq 6^{\circ} \mathrm{C}\right)$ in Poland reached 231 and showed spatial variability. A high increase in Tmax, above 10 cases/year, usually occurred at the Baltic Sea coast and in the foothills of the mountains (Figures $5 a$ and $6 a$ ). The least cases of such changes occurred in the belt of lakelands (below 8). 

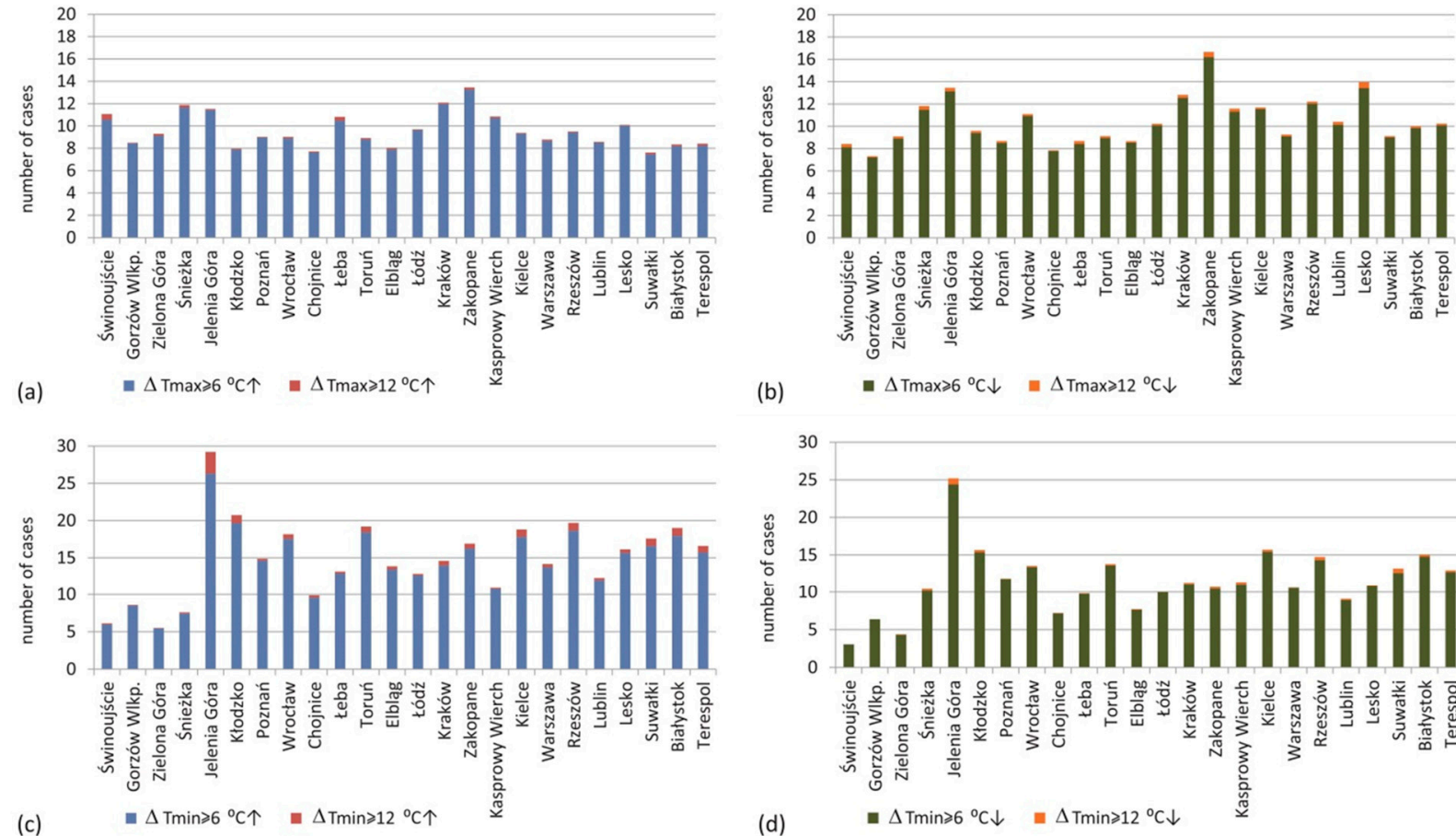

(b)

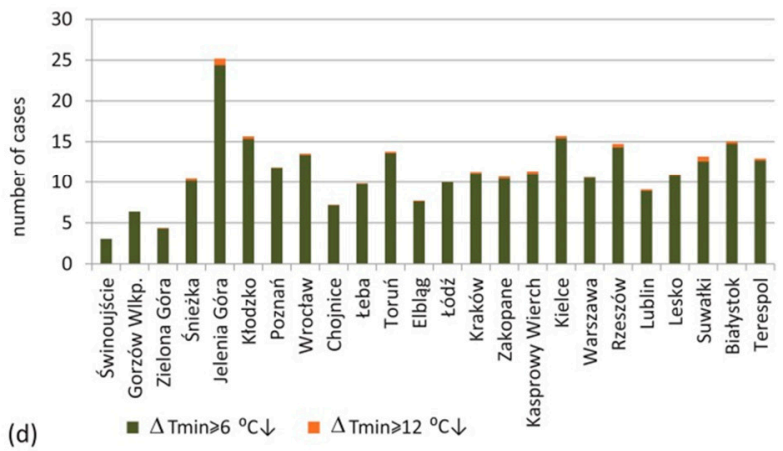

Figure 5. Mean annual number of cases of large and very large day-to-day increase $(\uparrow ;(\mathbf{a}, \mathbf{b}))$ and decrease $(\downarrow ;(\mathbf{c}, \mathbf{d}))$ in Tmax and Tmin in Poland in years 1966-2015 (stations ordered according to their longitude).

Decreases in large changes in $\operatorname{Tmax}\left(\Delta \operatorname{T\operatorname {max}} \downarrow \geq 6^{\circ} \mathrm{C}\right)$ were recorded in Poland on average 252 times in a year, and their number increased from the north-east to the south-west of the country. They most commonly occurred in the foothills of the Sudetes and the Carpathians (more than 12), and most seldom in north-western Poland (below 8) (Figures $5 \mathrm{~b}$ and $6 \mathrm{~b}$ ). Very large increases in maximum air temperature $\left(\Delta \operatorname{Tmax} \uparrow \geq 12{ }^{\circ} \mathrm{C}\right)$ are very rare: up to 0.5 cases annually in Świnoujście and occasional occurrences in central Poland (Figures $5 \mathrm{c}$ and $6 \mathrm{c}$ ). Very large decreases in $\operatorname{Tmax}\left(\Delta \operatorname{Tmax} \downarrow \geq 12^{\circ} \mathrm{C}\right)$ were also infrequent: up to 0.5 cases/year at the Carpathian foothills (Figures $5 \mathrm{~d}$ and $6 \mathrm{~d}$ ).

The spatial diversity of the considerable day-to-day maximum temperature changes is the reflection of the local conditions impact. Along the Baltic Sea coast, changes in circulation directions may trigger abrupt temperature swings as a result of air moving in from over warm land or cool sea (or the other way around). Such patterns are mostly typical of late spring and early summer, as Ciaranek [30] pointed out. As a result of the local air circulation causing thermal inversion in the foothills, sudden temperature changes take place. Comparing the temperature changes at foothill stations characterized by the highest mean annual values, it can be noticed that the Jelenia Góra station is located in the lowest part of the valley, and the Zakopane station lies not in the lowest, but in the central part of the inlet cone, which gradually descends towards the north. Moreover, as Tang and Leng [14] note, cloud cover is either the major indicator of the summer mean daily maximum temperature changes (the effect) or the important local factor influencing the changes (the cause). Cloud cover is negatively correlated with mean daily maximum temperature variation in spring and autumn at the middle latitudes of North America [14]. 

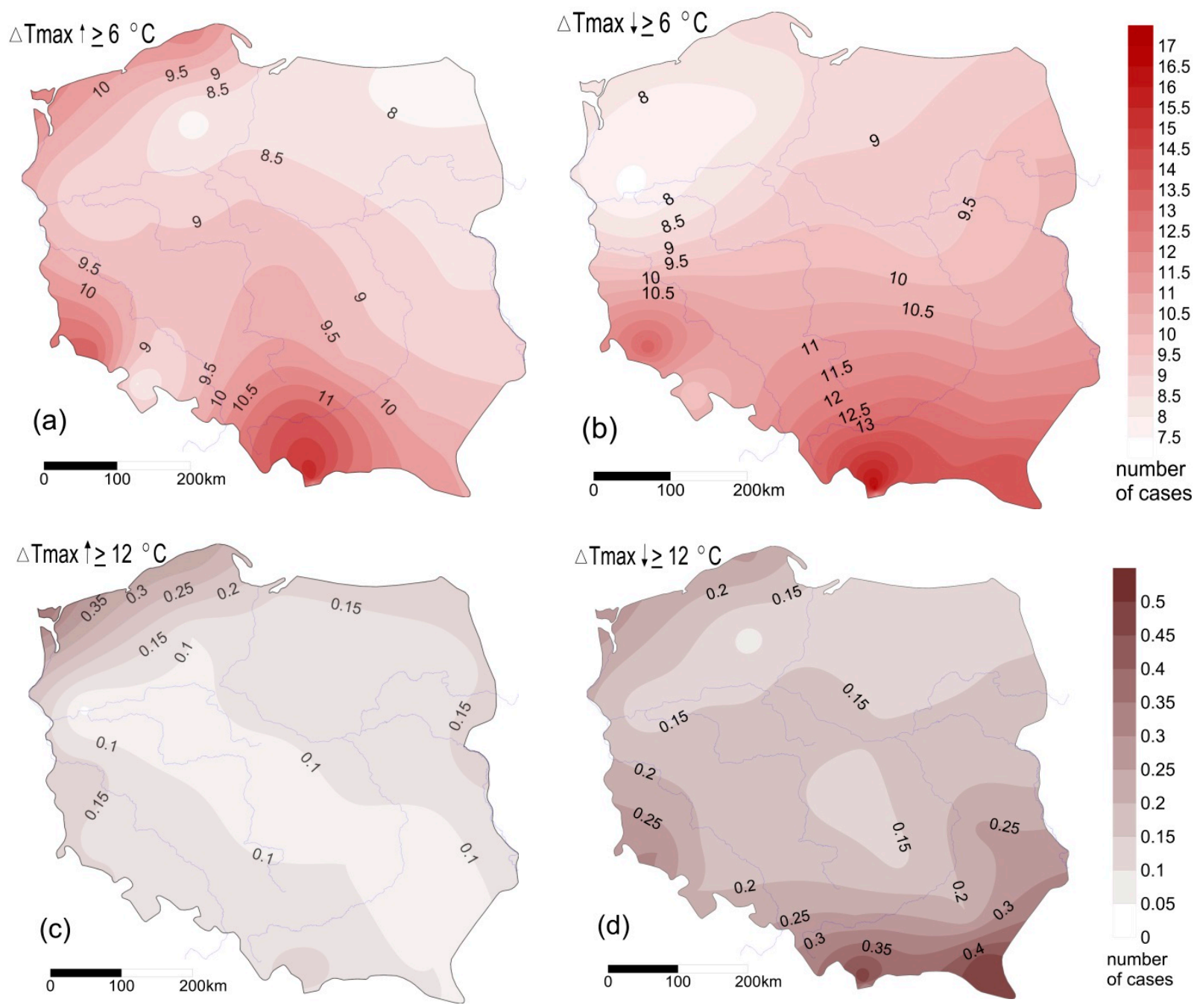

Figure 6. Spatial distribution of annual averages of large interdiurnal increases (a) and decreases (b) and very large increases (c) and very large decreases (d) in Tmax in Poland in the years 1966-2015.

Large increases in $\operatorname{Tmin}\left(\Delta \operatorname{Tm} \min \uparrow \geq 6{ }^{\circ} \mathrm{C}\right)$ in Poland occurred 356 times a year. Their number generally increased from the west to the east of the country, varying from 6 cases in Zielona Góra and Świnoujście to 29 cases annually in Jelenia Góra (Figures 5a and 7a). Decreases in large changes in $\operatorname{Tmin}\left(\Delta \operatorname{Tmin} \downarrow \geq 6^{\circ} \mathrm{C}\right)$ in Poland were recorded on average 275 times in a year, and the spatial distribution of their number was variable (Figures $5 b$ and $7 b$ ). They occurred most seldom in the north-western part of the country with the lowest number of cases recorded in Świnoujście (3 times in a year). The highest number of large decreases in Tmin was recorded in Jelenia Góra (more than 25). Very large increases in minimum air temperature $\left(\Delta \operatorname{Tm} \operatorname{in} \uparrow \geq 12{ }^{\circ} \mathrm{C}\right)$ were the most common of all the very large variations within the range of 0.1 cases / year in northeastern Poland to 2.9 cases annually in Jelenia Góra (Figures $5 \mathrm{c}$ and $7 \mathrm{c}$ ). Very large decreases in $\operatorname{Tmin}\left(\Delta \operatorname{Tmin} \downarrow \geq 12^{\circ} \mathrm{C}\right)$ did not exceed 0.6 cases a year in Suwałki (Figures $5 d$ and $7 d$ ). 

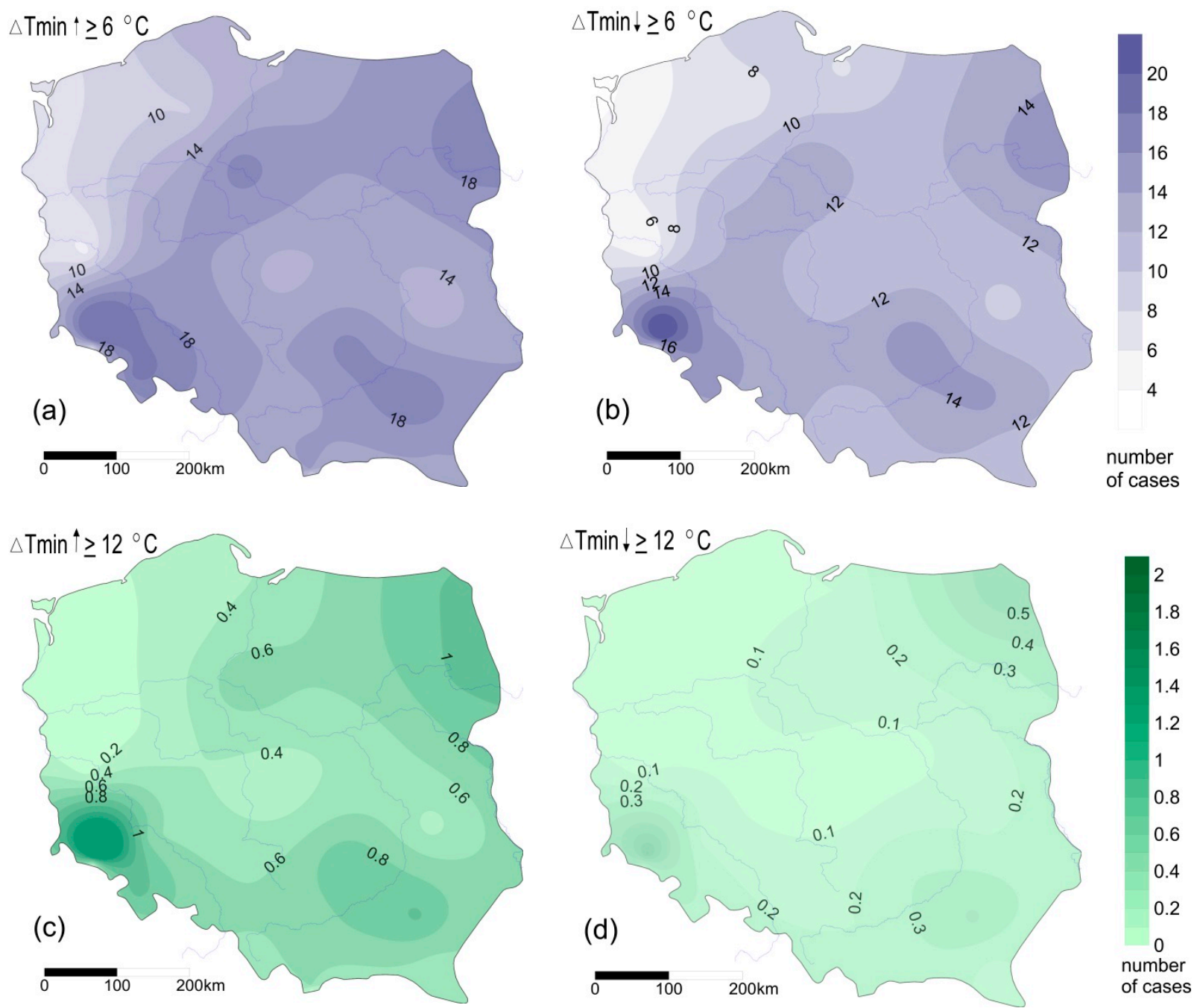

Figure 7. Spatial distribution of annual averages of large interdiurnal increases (a) and decreases (b) and very large increases (c) and very large decreases (d) in Tmin in Poland in the years 1966-2015.

Generally, the number of large changes in Tmin in Poland is the lowest in the northwestern part and increases east and southward. The increasing number of cases towards the east of the country confirms the intensification of thermal continentalism in this direction. The presented results are consistent with the results of the research of Panfil and Dragańska [5], who showed that large $\left(\geq 6^{\circ} \mathrm{C}\right)$ day-to-day changes in temperature occurred most frequently in the east of their study area. On the other hand, frequent large changes in temperature in the Jelenia Góra valley for example, result also from the local circulation conditions in this area, i.e., foehn winds.

In the analysed period, the mean monthly number of days with large changes in Tmax $\left(\geq 6{ }^{\circ} \mathrm{C}\right)$ in Poland reached 20 cases in a year, including 9.5 increases and 10.5 decreases. The number of days with these changes in Tmin reached 26, including 15 increases and 11 decreases. Large changes in Tmax dominated in April and May, Tmin-from December to March (Figure 8). The lowest number of large changes in Tmax occurred in February and the period from August to November. Large changes in Tmin occurred most seldom from June to August and in November. 


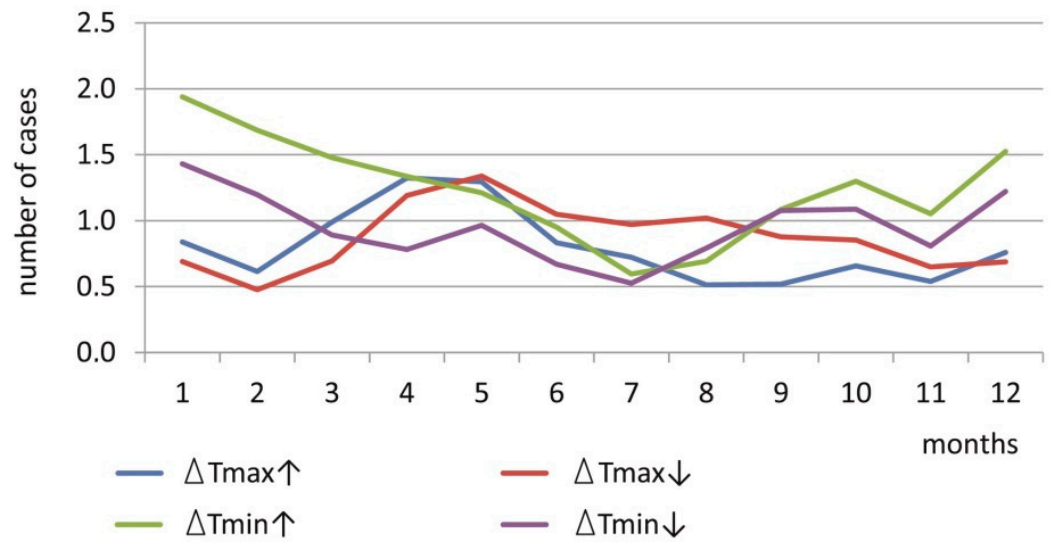

Figure 8. Mean monthly number of cases of large day-to-day increase $(\uparrow)$ and decrease $(\downarrow)$ in Tmax and Tmin in Poland in the years 1966-2015.

Among the annual courses of large changes in maximum air temperature in all the analysed stations, coastal stations stand out (Łeba and Świnoujście), showing the highest variability of the number of cases in a year (Figure 9). The highest monthly number of increases and decreases in Tmax is observed in May there, and their lowest number in November. Very large changes in $\operatorname{Tmax}\left(\geq 12^{\circ} \mathrm{C}\right)$ also occur most frequently in these stations, with the highest number of cases recorded in May. The annual course of the number of both increases and decreases in Tmax reached culmination in spring, in accordance with the results of Panfil [28]. In the mountain stations (Śnieżka and Kasprowy Wierch), the annual course of maximum temperatures changes is the same, i.e., the highest monthly number is observed in cold seasons, and the lowest in the half-year. The opposite annual course of Tmax versus Tmin large changes is characteristic for Zielona Góra- the station situated in the western part of Poland. In turn, the specificity of the annual course on the station in the north-eastern part of the country is the very high frequency of large changes in Tmin in winter.
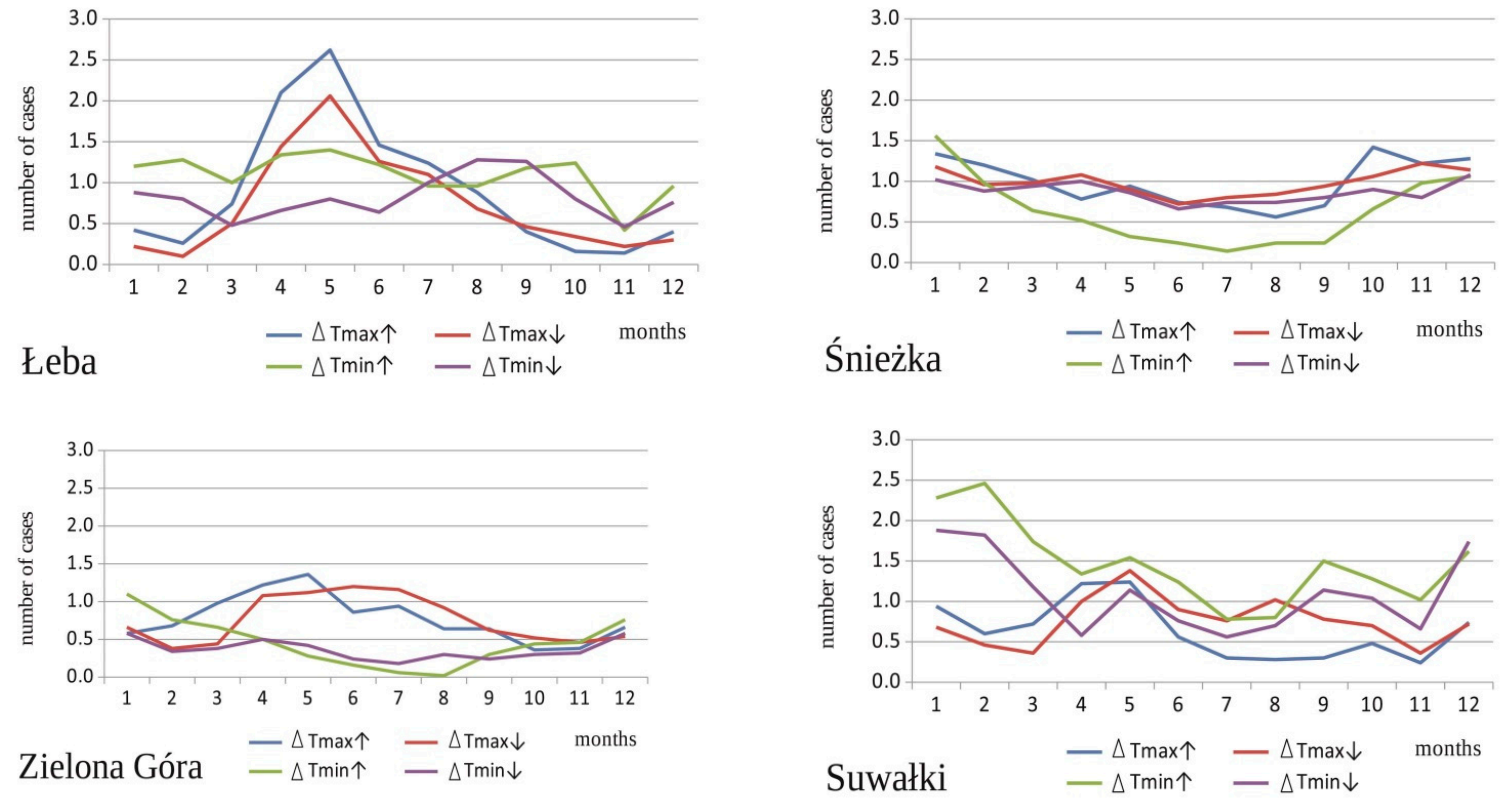

Figure 9. Mean monthly number of cases of large day-to-day increase ( $\uparrow$ ) and decrease $(\downarrow)$ in Tmax and Tmin selected stations in Poland in the years 1966-2015. 
Changes in Tmin in the majority of the stations in Poland both increase and decrease and are more considerable in winter than in summer, similarly proved by Wibig [27]. Fortuniak et al. [25] confirm that such considerable changes in temperature are usually observed in the winter period as a result of the advection of both cool and warm air masses. The temperature swings, which are most strongly felt by the human body and are not prepared to rapidly adapt to them, are mainly those occurring in winter and spring as a result of the advection of thermally different air masses, Kossowska-Cezak [2] explained. Kossowski [48] pointed out that considerable short-term variations in temperature most frequently occur in the cooler half of the year when the air masses over Poland are the most thermally diverse and weather fronts are most frequent. In the summer months, such shifts are smaller and happen less frequently, while changes in cloud cover, which influence night-time radiation cooling, become a contributing factor [10,31].

The occurrence of extreme temperature changes in Poland varies in time and space in Poland, which proves dependence on the local conditions. During the period considered in all the analysed stations in Poland, the highest daily decrease in Tmax exceeded $14{ }^{\circ} \mathrm{C}$, and the increase exceeded $13{ }^{\circ} \mathrm{C}$ (Figure 10). The highest decreases in particular stations varied from $-14.1{ }^{\circ} \mathrm{C}$ in Torun (19 October 1967) to $-20.3{ }^{\circ} \mathrm{C}$ in Poznań (30 December 1978) and in Kraków (23 January 2006). The extreme Tmax decreases occurred mostly in winter. Maximum increases in Tmax ranged from $13.1^{\circ} \mathrm{C}$ in Rzeszów (11 February1966) to $19.8^{\circ} \mathrm{C}$ in Świnoujście (14 May1985). In the majority of stations, the values were recorded in April. In such cases, a sudden increase in air temperature may lead to premature onset of the vegetative period, while another rapid temperature drop may result in frost damage in field crops and orchards. This may cause great losses to farmers and have an impact on the human body as well [30].

The highest daily decrease in Tmin exceeded $10^{\circ} \mathrm{C}$ and the increase $12^{\circ} \mathrm{C}$. Maximum decreases in Tmin in particular stations are values from $10.3^{\circ} \mathrm{C}$ in Świnoujście (13 December 2001) to $22.1^{\circ} \mathrm{C}$ in Kielce (7 January 1987). Maximum increases in Tmin varied from $12.8^{\circ} \mathrm{C}$ in Zielona Góra (6 February 2001) to $22.8^{\circ} \mathrm{C}$ in Jelenia Góra (4 December 1973). Extreme values of Tmin changes occurred mostly in winter.

The large temperature changes can have strong impacts on local native plant distributions, as well as horticulture and agriculture. Mountainous terrain is well known for the creation of local "frost hollows" due to cold air drainage [49]. Unfortunately, winter thaws can have an immense impact on agricultural or horticultural activities as well as losses in transport and buildings and infrastructure.

The share of temperature decreases and increases in the case of Tmax is more aligned in comparison to Tmin in the study period. On average, in Poland, in $49.3 \%$ of cases, an increase in Tmax occurred, and in $48.9 \%$ of cases a decrease occurred. While according to Ciaranek [30], in the years 1961-2010 in Poland, the share of increases in large changes in Tmax was lower than in the case of decreases and showed spatial variability. A day-to-day decrease in Tmin occurs more frequently, averaging $50.6 \%$ of cases. The share of increases in Tmin averages $47.7 \%$ in Poland. As Piskala and Huth [50] note, the asymmetries in the large temperature changes $\left(5^{\circ} \mathrm{C}\right.$ and larger) were related to the passages of all three front types in winter and to the passages of cold fronts in summer.

Interdiurnal Tmax increases occur more frequently in the south-west of Poland. The stations in the north-western part of the country are characterised by the advantage of a decrease in Tmax over a decline. The remaining area is dominated by interdiurnal increase in Tmax.

The majority of the stations are characterised by the greatest advantage of Tmin decreases over increases. The highest located stations stand out: at Śnieżka, the highest peak in Karkonosze Mountains, the T min large increases prevail; and at Kasprowy Wierch in Tatra Mountains, the large changes are aligned.

Considerably more day-to-day changes in minimum than maximum temperature increase occurred in the analysed period. This is in accordance with the results of Panfil [28]. Similarly, Fortuniak et al. [25] determined that at the scale of the entire year, temperature 
increases are characterised by a lower mean value, but higher frequency than temperature decreases. This pattern is particularly evident in the warm season of the year. Regarding day-to-day variations, Piotrowicz et al. [31] pointed out that large decreases in Tmax were more numerous than in Tmin, whereas the opposite was true for large increases-they were more numerous in the case of Tmin than for Tmax.
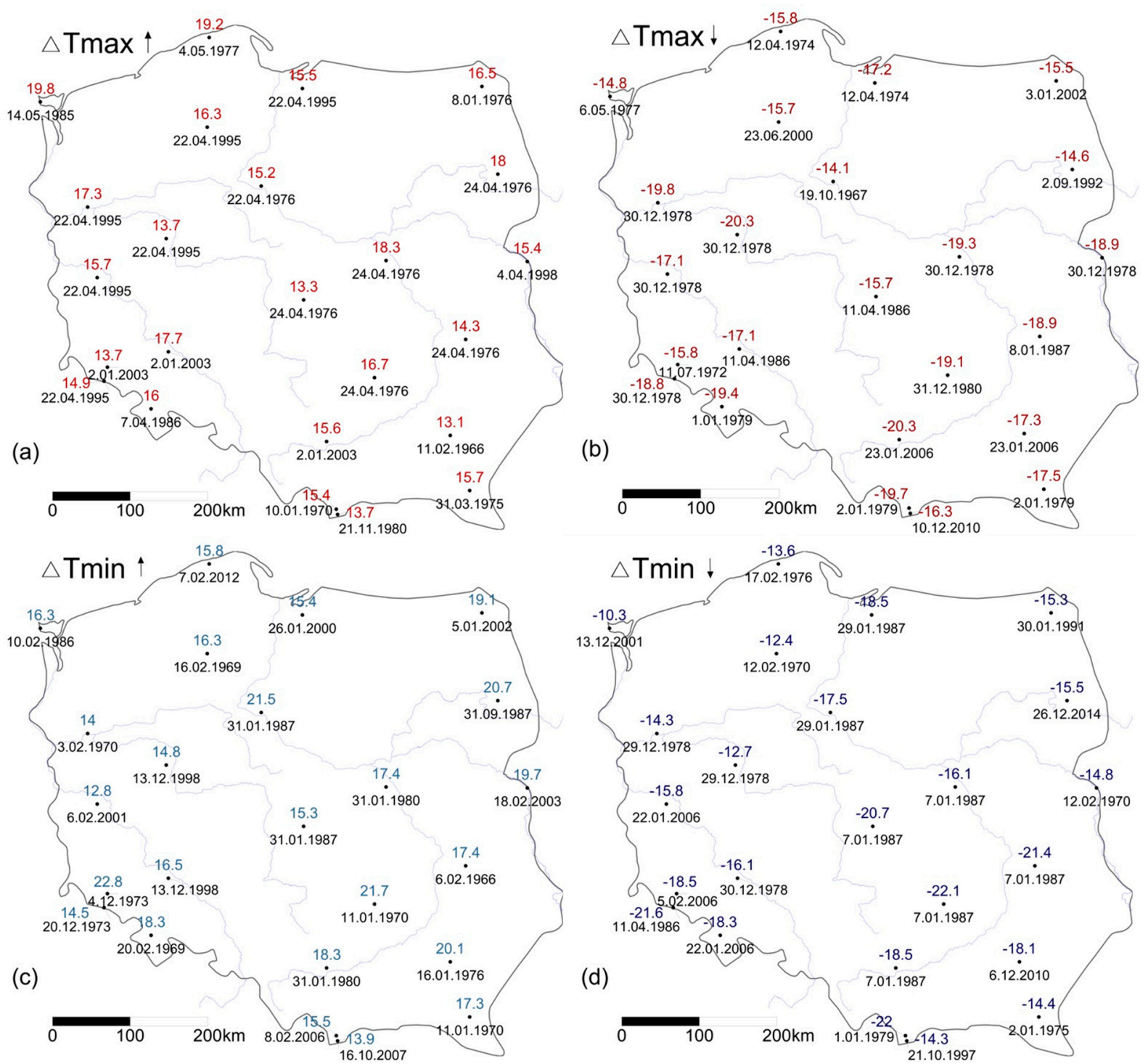

Figure 10. The highest interdiurnal increases and decreases in $\operatorname{Tmax}(\mathbf{a}, \mathbf{b})$ and Tmin (c,d) in Poland in 1966-2015 with the date of its occurrence.

\subsection{Influence of Atmospheric Circulation}

The particular atmospheric circulation patterns cause certain thermal conditions in a research area. In the years 1966-2015, circulation types WZ (15.5\%) and BM (10.8\%) occurred the most frequently (Figure 11). The following types occurred the most seldom, with a frequency below $1 \%$ : NA $(0.6 \%)$ and SZ $(0.8 \%)$. In the aforementioned period, cyclonic circulation considerably dominated (57.0\%) over anticyclonic circulation (41.9\%). 


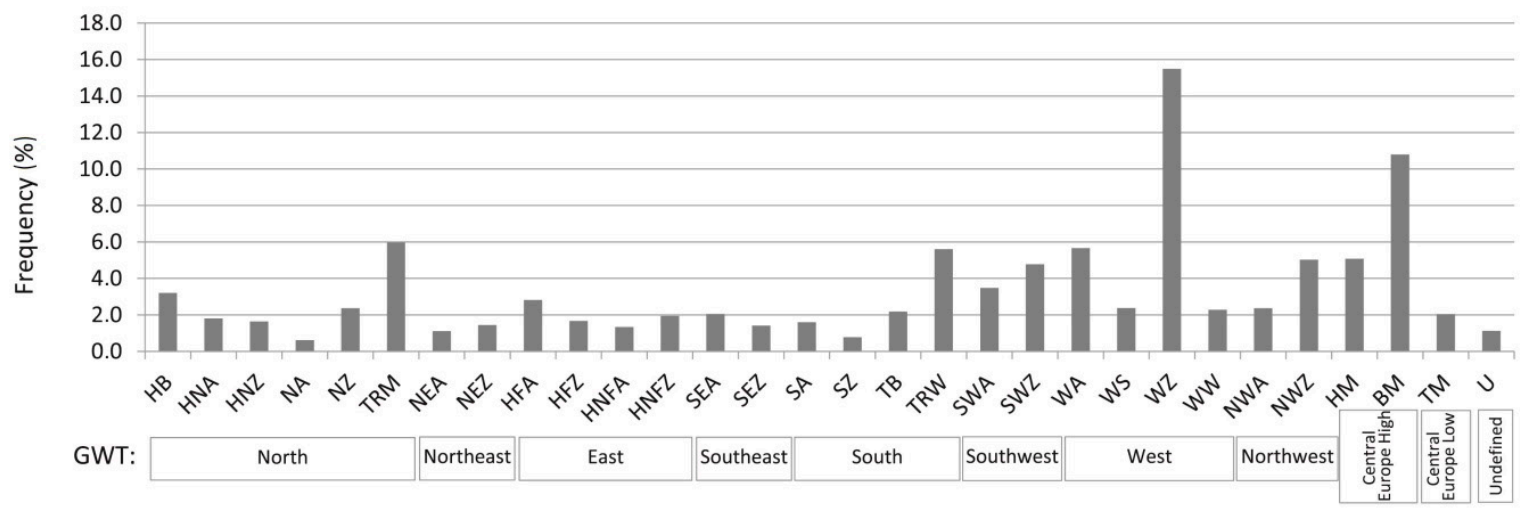

Figure 11. Frequency of Grosswetterlagen (GWL) circulation types in the years 1966-2015. Explanations of the GWL types: see Table 1.

Large day-to-day changes in Tmax primarily occurred during cyclonic circulation (Table 3). The highest probability of occurrence of a large increase in maximum air temperature was recorded during SWZ (8.3\%) (Figure 12a). High probabilities of $\Delta \mathrm{Tmax} \geq 6{ }^{\circ} \mathrm{C}$ also occurred during types TB $(8.0 \%)$, TRW $(6.5 \%)$ and SZ (6.3\%). The advection of warm air masses is the cause of the temperature rise. The lowest probability of a large increase in Tmax was related to TRM and HB (1.5\% each). A large decrease in Tmax was the most probable during HNZ circulation (9.1\%) (Figure 12b). Such changes also occurred relatively frequently with TRM type $(7.8 \%)$. The influence of cold air masses advection is reflected in the temperature decline. They were recorded most seldom during types SZ (1.5\%) and TB $(1.8 \%)$.

Table 3. Frequency (\%) of the occurrence of large interdiurnal extreme air temperature changes in the particular GWL circulation types in the years 1966-2015. For explanations of the circulation types, see Table 2.

\begin{tabular}{ccccc}
\hline \multirow{2}{*}{ Circulation Type } & \multicolumn{2}{c}{ Increase } & \multicolumn{2}{c}{ Decrease } \\
\cline { 2 - 5 } & $\mathbf{T} \mathbf{m a x}>\mathbf{6}^{\circ} \mathbf{C}$ & $\mathbf{T} \min >\mathbf{6}{ }^{\circ} \mathbf{C}$ & $\mathbf{T m a x}>\mathbf{6}{ }^{\circ} \mathbf{C}$ & $\mathbf{T m i n}>\mathbf{6 ~}^{\circ} \mathbf{C}$ \\
\hline Westerly & 22.7 & 30.7 & 19.5 & 20.8 \\
Northerly & 17.6 & 23.7 & 39.5 & 32.9 \\
Easterly & 18.4 & 11.3 & 16.5 & 18.8 \\
Southerly & 29.4 & 21.7 & 12.7 & 13.9 \\
Central & 8.6 & 10.0 & 9.2 & 9.9 \\
Cyclonic & 58.7 & 59.8 & 54.8 & 43.0 \\
Anticyclonic & 37.5 & 37.6 & 42.6 & 53.3 \\
\hline Undefined & 3.8 & 2.6 & 2.6 & 3.7 \\
\hline
\end{tabular}

A very high increase in Tmax over the predominant territory of Poland, i.e., a day-today increase of more than $12{ }^{\circ} \mathrm{C}$, occurred in the study period sporadically. It occurred one time during the following circulation types: NZ, HNZ, SWZ, and SEZ. A rapid day-to-day decrease in maximum temperature, i.e., a decrease by more than $12{ }^{\circ} \mathrm{C}$, occurred seven times in the study period in the majority of the analysed stations during the circulation types: HNFZ, WS, WZ, HNFA, NZ, HM, and WA.

The southerly and westerly types especially favoured the increase of Tmax, causing the advection of warm air masses over the area of Poland. Increase in air temperature for southern and south-western circulation could be related to the foehn effect on the northern slopes of Carpathian Mountains for the station in the south of Poland. The decrease of Tmax occurred with the highest probability during the northerly types as the cold air masses reached Poland. 


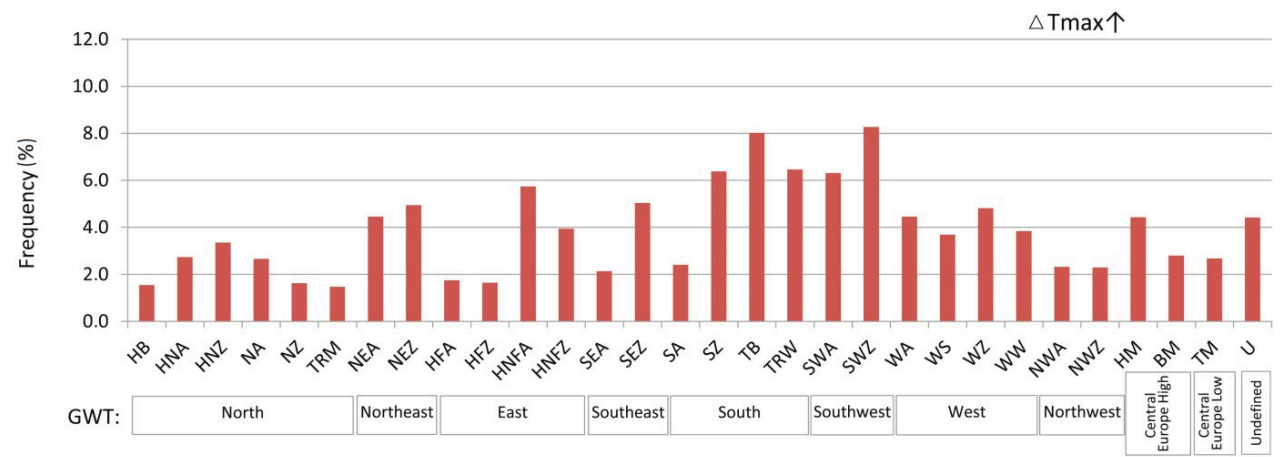

(a)

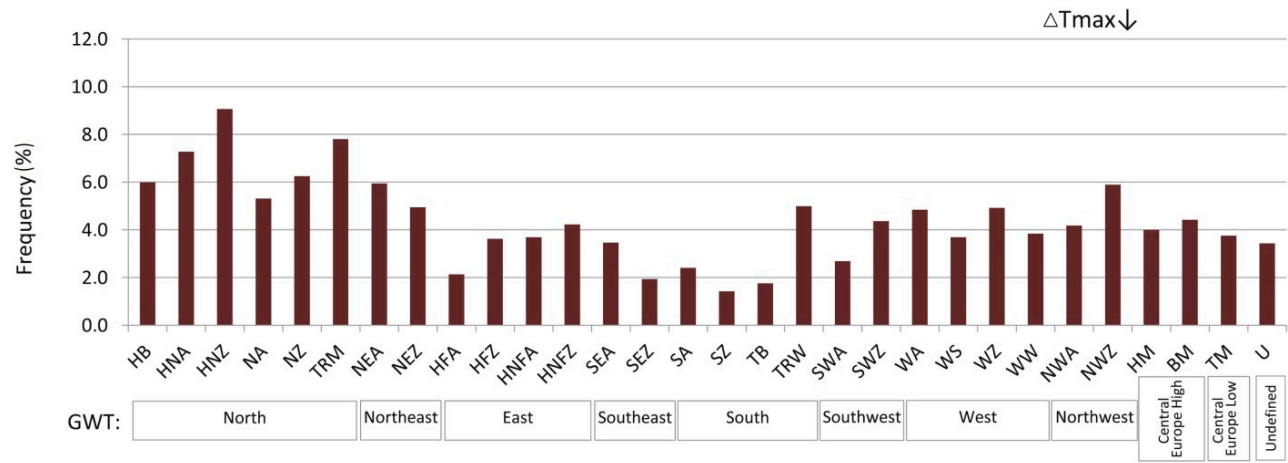

(b)

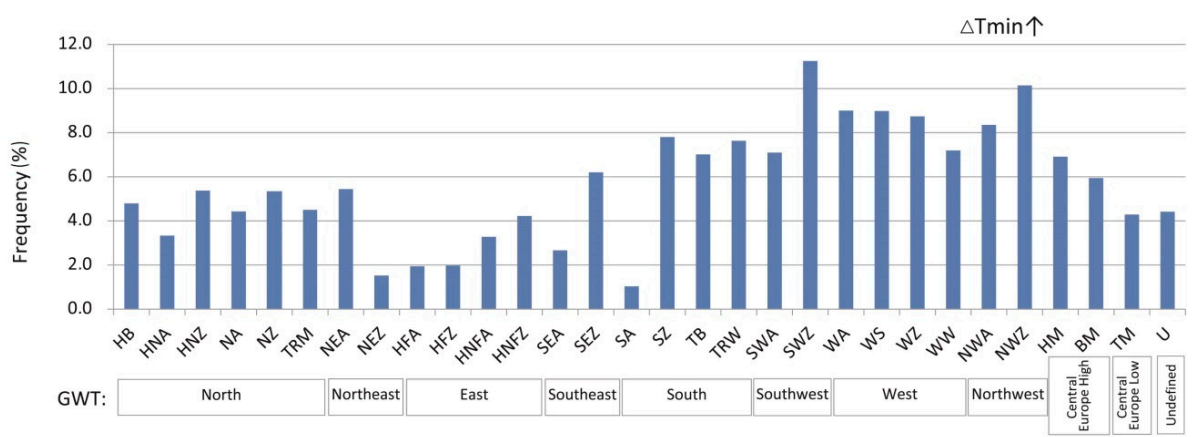

(c)

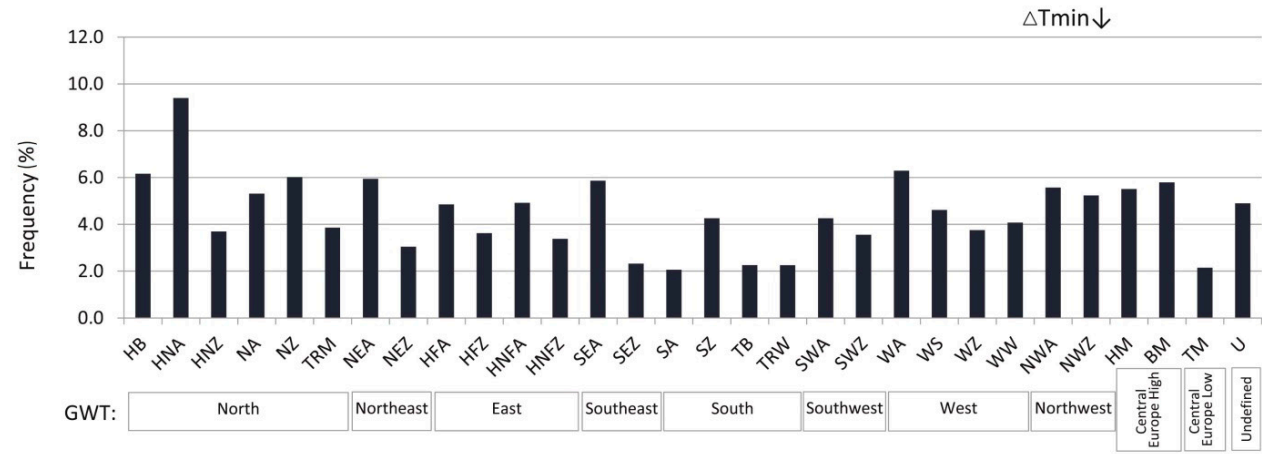

(d)

Figure 12. Probability of the occurrence of large interdiurnal of extreme air temperature changes in the particular GWL circulation types in the years 1966-2015: (a) $\Delta \operatorname{Tmax} \uparrow$; (b) $\Delta \operatorname{Tmax} \downarrow$; (c) $\Delta \operatorname{Tm} \min \uparrow$; (d) $\Delta \operatorname{Tmin} \downarrow$. Explanations of the GWL types: see Table 1. 
The obtained results coincide with earlier studies. This is confirmed by research by Wibig [27], according to which western types are characterised by an increase in temperature, but maintain shorter for 4-5 days, and day-to-day changes are lower than in the case of eastern types. Eastern types are characterised by a day-to-day decrease in temperature maintained for 5-6 days. Panfil [29], analysing the dependencies of large changes in extreme temperatures on the atmospheric circulation in Olsztyn, proved a particular impact of the northern and westerly components.

Large day-to-day increase in Tmin $\left(\geq 6^{\circ} \mathrm{C}\right)$ more often occurred during cyclonic circulation types $(59.8 \%)$, while the anticyclonic circulation types caused large Tmin declines $(53.3 \%)$ (Table 3). The highest probability of occurrence of a large increase in minimum temperature was recorded during SWZ (11.3\%) and NWZ (10.1\%) (Figure 12c). SWZ circulation brings the warmer air masses over Poland, which may cause the large Tmin increase. If the polar maritime air flows to Poland during the NWZ circulation in winter, it may induce a thaw and large increase in temperature as well. The lowest probability of a high increase in Tmin was usually related to circulation types SA (1.0\%) and NEZ (1.5\%). The highest probability of occurrence of a large decrease in Tmin was recorded in type HNA (9.4\%) (Figure 12d). A higher number of large day-to-day changes in Tmin was also probable during circulation WA $(6.3 \%)$, as well as HB (6.2\%). The advection of air masses from the northern direction and the strong effective radiation in the anticyclonic conditions cause the Tmin declines. The lowest probability of a high day-to-day decrease in Tmin occurred in types SA and TM $(2.1 \%$ each).

Very large changes in Tmin were recorded more frequently over a prevalent area of Poland. Day-to-day changes in Tmin $\geq 12{ }^{\circ} \mathrm{C}$ occurred 36 times in the period 1966-2015, and the highest probability of their occurrence was determined during SZ, NZ, HB, and SWZ types. A rapid decrease in Tmin was recorded six times: twice during type WS and one occurrence each during types: WZ, NZ, NWZ, and BM. All these cases of rapid changes in Tmin occurred in winter.

Large Tmin increase was associated with the westerly inflow mainly, and in turn, decrease was associated especially with the northerly advection. The western circulation is leading to an increase in minimum temperature in winter, causing thaws. The free passages of polar oceanic air masses contribute to cooling down in the warm season. In winter, high decreases in temperature correspond to circulation types of the easterly component, particularly from the northern sector [19].

According to previous studies, extreme values of air temperature, rapid cooling or warming depending on the season, are associated with anticyclonic circulation and strong highs blocking the zonal circulation [7-9]. The radiative processes are most effective during clear sky weather days under anticyclonic conditions. The persistence of anticyclonic circulation for several days leads to increases in daytime temperatures, due to the positive radiation balance in summer [8,50,51]. While Kuziemska [52] pointed to the important role of advection in shaping considerable temperature anomalies in winter, both positive and negative, the most high temperature decreases occur when the inflow of cold air is accompanied by strong effective radiation, i.e., in the case of anticyclonic circulation types. In summer, the dominant role in shaping thermal conditions is played by insolation, and secondary, although still important, by advection. Kossowska-Cezak [2] evidenced that day-to-day temperature changes also depend on the sequence of circulation types. Day-today changes in minimum and maximum temperatures are usually the highest between the second and fourth day of occurrence of a given circulation, and then they decrease or even change the sign to the opposite one [27]. Sfîcă et al. [18] identified two major spatial changes in cloud cover over Europe, in connection with atmospheric circulation, associated with the latitudinal shift towards the north of the westerly circulation. The changes in cloud cover distribution and also in radiation fluxes leading to temperature changes, imposed by these shifts in atmospheric circulation over the continent, are higher in Eastern and Central Europe. 
Temperature changes at moderate latitudes remain in close relation to the variability of atmospheric circulation, particularly in winter when insolation plays a secondary role in forming weather conditions [27]. However, besides the weather situation and the advection of various air masses, the scale of short-term temperature changes is influenced by local factors, such as relief and land cover [53]. Tomczyk [54] suggested that the daily minimum temperature is less associated with the regional circulation patterns than the daily maximum temperature and more influenced by local factors instead. In turn, Piotrowicz et al. [31] suppose that the short-term variation in Tmax and Tmin decreasewhich has been gradual over the entire analysed long-term period, without clear and sudden changes to the overall trend-was largely influenced by anthropogenic factors. The decrease in the daily temperature range is partially related to increases in cloud cover. Furthermore, a large number of atmospheric and surface boundary conditions are shown to differentially affect the maximum and minimum temperatures. For rural sites, day-to-day temperature variation was typically greater for Tmin than Tmax. The opposite was found for urban locations, with statistically significant stronger signals for larger cities [33].

\section{Summary and Conclusions}

The spatial and temporal variability of large interdiurnal temperature changes in Poland indicates the local conditions as well as the atmospheric circulation impact. The research on large day-to-day changes in extreme temperature in Poland in the period 1966-2015 showed that there was a statistically significant increase in the number of large changes in both Tmax and Tmin, although the fluctuations show spatial variability. Higher fluctuations of maximum than minimum temperature were recorded over the majority of the territory of the country. The number of large changes in Tmax increases from north to south, and the number of large changes in Tmin from north to east and south of Poland reflect the range of the effect of marine and continental properties on the climate of Poland. The highest number of large Tmax changes in the mountain foothills indicates the influence of local relief. The research carried out showed that in Poland, day-to-day changes in Tmin exceeding 6 degrees are considerably more frequent in winter. Large changes in Tmax, however, show a higher frequency in spring.

Large changes in Tmax and Tmin are mainly recorded during cyclonic circulation, however, the anticyclonic circulation types favour especially large decreases in Tmin. The study showed the variability of the direction of atmospheric advection favouring changes in Tmax and Tmin. Large increases in Tmax were favoured by southerly circulation type, and in Tmin were primarily favoured by westerly types. The decreases in both Tmax and Tmin occurred the most frequently during the northerly type of circulation.

The analysis of the dependency of considerable temperature changes on atmospheric circulation is in accordance with the Grosswetterlagen (GWL) classification in this research. However, for future works, COST733 software would be a different approach for similar studies. In order to examine correspondence between different methods for circulation type classification, a dataset of classification catalogs for 12 different European regions has been created using a specially developed software package [55]. Twenty-seven basic automatic classification methods have been applied in several variants to different input datasets describing atmospheric circulation. Together with six manual classifications, a total of 33 methods are available for inter-comparison.

Linkages of the observed changes in Tmax, Tmin and the diurnal temperature range to large-scale climate forcings, such as cloud cover, precipitation, anthropogenic increases in sulfate aerosols, greenhouse gases, or biomass burning, remain tentative [21,33,56]. Future changes in Tmax, Tmin and diurnal temperature range urgently need to be better understood as they provide vital scientific information for adapting to temperature changes and effectively managing the related disaster risks [50]. Future research on temporal and spatial variability and the influence of particular local conditions on the occurrence of large changes in extreme temperatures would not only be valuable but also necessary. 
Author Contributions: All authors have read and agreed to the published version of the manuscript.

Funding: This research received no external funding.

Data Availability Statement: The data presented in this study are openly available at https:/ dane. imgw.pl/data/dane_pomiarowo_obserwacyjne/.

Acknowledgments: I would like to thank the anonymous reviewers for their valuable comments and suggestions to improve quality of the paper.

Conflicts of Interest: The author declares no conflict of interest.

\section{References}

1. IPCC. Climate Change 2013: The Physical Science Basis. Contribution of Working Group I to the Fifth Assessment Report of the Intergovernmental Panel on Climate Change; Stocker, T.F., Qin, D., Plattner, G.-K., Tignor, M., Allen, S.K., Boschung, J., Nauels, A., Xia, Y., Bex, V., Midgley, P.M., Eds.; Cambridge University Press: Cambridge, UK, 2013; 1535p. [CrossRef]

2. Kossowska-Cezak, U. Duże zmiany temperatury z dnia na dzień a cyrkulacja atmosferyczna. Przegl. Geofiz. 1987, 32, $289-302$.

3. Rebetez, M. Changes in daily and nightly day-to-day temperature variability during the twentieth century for two stations in Switzerland. Theor. Appl. Climatol. 2001, 69, 13-21. [CrossRef]

4. Zhuang, Y.; Zhang, J. Diurnal asymmetry in future temperature changes over the main Belt and Road regions. Ecosyst. Health Sustain 2020, 6, 1749530. [CrossRef]

5. Panfil, M.; Dragańska, E. Związki korelacyjne między wskaźnikami NAO wg Jones'a oraz Hurrela a warunkami termicznymi i opadowymi dla Polski północno-wschodniej. Acta Agrophys. 2004, 3, 133-142.

6. Wibig, J.; Głowicki, B. Trends in minimum and maximum temperature in Poland. Clim. Res. 2002, 20, 123-133. [CrossRef]

7. Porebska, M.; Zdunek, M. Analysis of extreme temperature events in Central Europe related to high pressure blocking situations in 2001-2011. Meteorol. Z. 2013, 22, 533-540. [CrossRef]

8. Tomczyk, A.M.; Bednorz, E. Heat waves in Central Europe and their circulation conditions. Int. J. Climatol. 2016, 36, 770-782. [CrossRef]

9. Wibig, J. Heat waves in Poland in the period 1951-2015: Trends, patterns and driving factors. Meteorol. Hydrol. Water Manag. 2018, 6, 37-45. [CrossRef]

10. Moberg, A.; Jones, P.D.; Barriendos, M.; Berstoem, H.; Camuffo, D.; Cocheo, C.; Davies, T.D.; Demareae, G.; Maugeri, M.; MartinVide, J.; et al. Day-today-temperature variability trends in 160- to 275-year-long European instrumental records. J. Geophys. Res. 2000, 105, 22849-22868. [CrossRef]

11. Cattiaux, J.; Douville, H.; Schoetter, R.; Parey, S.; You, P. Projected increase in diurnal and interdiurnal variations of European summer temperatures. Geophys. Res. Lett. 2015, 42, 899-907. [CrossRef]

12. Lobell, D.B.; Bonfils, C.; Duffy, P.B. Climate change uncertainty for daily minimum and maximum temperatures: A model inter-comparison. Geophys. Res. Lett. 2007, 34, L05715. [CrossRef]

13. He, B.; Huang, L.; Wang, Q. Precipitation deficits increase high diurnal temperature range extremes. Sci. Rep. 2015, 5, 12004. [CrossRef]

14. Tang, Q.; Leng, G. Changes in cloud cover, precipitation, and summer temperature in North America from 1982 to 2009. J. Clim. 2013, 26, 1733-1744. [CrossRef]

15. Del Genio, A.D.; Wolf, A.B. The temperature dependence of the liquid water path of low clouds in the southern Great Plains. J. Clim. 2000, 13, 3465-3486. [CrossRef]

16. Norris, J.R.; Iacobellis, S.F. North Pacific cloud feedback inferred from synoptic-scale dynamic and thermodynamic relationships. J. Clim. 2005, 18, 4862-4878. [CrossRef]

17. Boucher, O.; Randall, D.; Artaxo, P.; Bretherton, C.; Feingold, G.; Forster, P.; Kerminen, V.-M.; Kondo, Y.; Liao, H.; Lohmann, U.; et al. Clouds and aerosols. In Climate Change 2013: The Physical Science Basis. Contribution of Working Group I to the Fifth Assessment Report of the Intergovernmental Panel on Climate Change; Stocker, T.F., Qin, D., Plattner, G.-K., Tignor, M., Allen, S.K., Doschung, J., Nauels, A., Xia, Y., Bex, V., Midgley, P.M., Eds.; Cambridge University Press: Cambridge, UK, 2013 ; pp. 571-657. [CrossRef]

18. Sfîcă, L.; Beck, C.; Nita, A.-I.; Voiculescu, M.; Birsan, M.-V.; Philipp, A. Cloud cover changes driven by atmospheric circulation in Europe during the last decades. Int. J. Climatol. 2020, 1-20. [CrossRef]

19. Kossowska-Cezak, U. Duże zmiany temperatury z dnia na dzień w Polsce. Przegl. Geofiz. 1982, 27, $197-214$.

20. Brazdil, R.; Budikova, M.; Auer, I.; Böhm, R.; Cegnar, T.; Fasko, P.; Gajič Capka, M.; Lapin, M.; Niedźwiedź, T.; Szalai, S.; et al. Trends of maximum and minimum daily temperature in Central and Southeastern Europe. Int. J. Climatol. 1996, 16, 765-782. [CrossRef]

21. Karl, T.R.; Jones, P.D.; Knight, R.W.; Kukla, G.; Plummer, N.; Razuvayev, V.N.; Gallo, K.P.; Lidesay, J.; Charlson, R.J.; Peterson, T.C. A new perspective on recent global warming: Assymetric trends of daily maximum and minimum temperature. Bul. Am. Meteorol. Soc. 1993, 74, 11007-11023. [CrossRef]

22. Kozłowska-Szczęsna, T.; Błażejczyk, K.; Krawczyk, B. Bioklimatologia Człowieka. Metody i ich Zastosowanie w Badaniach Bioklimatu Polski; Monografie 1; PAN IGiPZ: Warszawa, Poland, 1997. 
23. Tomczyk, A.M.; Szyga-Pluta, K.; Majkowska, A. Frost and frost-free periods in Poland and neighboring countries. Open Geosci. 2015, 7, 812-823. [CrossRef]

24. Tomczyk, A.M.; Szyga-Pluta, K.; Bednorz, E. Occurrence and synoptic background of strong and very strong frost in spring and autumn in Central Europe. Int. J. Biometeorol. 2020, 64, 59-70. [CrossRef] [PubMed]

25. Fortuniak, K.; Kłysik, K.; Wibig, J. Międzydobowa zmienność temperatury powietrza w Łodzi. Acta Geogr. Lodz. 2004, 89, 35-46.

26. DeGaetano, A.T. A method of infer observation time based on day-to-day temperature variations. J. Clim. 1999, 12, 3443-3456. [CrossRef]

27. Wibig, J. Wpływ cyrkulacji atmosferycznej na miedzydobowe zmiany temperatury minimalnej i maksymalnej. Prace Studia Geogr. 2001, 29, 223-232.

28. Panfil, M. Zmiany i zmienność temperatur ekstremalnych z dnia na dzień w Polsce północno-wschodniej w okresie 1951-2000. Dok. Geogr. 2006, 32, 225-229.

29. Panfil, M. Duże zmiany międzydobowe temperatur ekstremalnych w drugiej połowie XX wieku. Acta Agrophys. 2007, 10, 649-658.

30. Ciaranek, D. Krókookresowe zmiany maksymalnej temperatury powietrza w półroczu chłodnym w Polsce. Acta Sci. Pol. Formatio Circumiectus 2016, 15, 49-58. [CrossRef]

31. Piotrowicz, K.; Ciaranek, D.; Guzik, I. Short-term variations in the air temperature in Krakow (Poland) as an indicator of climate change in Central Europe. Idojaras 2017, 121, 117-135.

32. Brunetti, M.; Buffoni, L.; Maugeri, M.; Nanni, T. Trends of minimum and maximum daily temperatures in Italy from 1865 to 1996. Theor. Appl. Climatol. 2000, 66, 49-60. [CrossRef]

33. Tam, B.Y.; Gough, W.A.; Mohsin, T. The impact of urbanization and the urban heat island effect on day to day temperature variation. Urban Clim. 2015, 12, 1-10. [CrossRef]

34. Niedźwiedź, T. Sytuacje Synoptyczne I Ich Wpływ na Zróżnicowanie Przestrzenne Wybranych Elementów Klimatu w Dorzeczu Górnej Wisty; Rozprawy Habilitacyjne Uniwersytetu Jagiellońskiego: Kraków, Poland, 1981; Volume 58.

35. Yarnal, B. Synoptic Climatology in Environmental Analysis; Belhaven Press: London, UK, 1993.

36. Salmi, T.; Maiittii, A.; Anttila, P.; Ruoho-Airola, T.; Amnel, T. Detecting Trends of Annual Values of Atmospheric Pollutants by the Mann-Kendall Test and Sen's Slope Estimates-The Excel Template Application MAKESENS; Volume 31, Publications on Air Quality; Finnish Meteorological Institute: Helsinki, Finland, 2002; pp. 1-35.

37. James, P.M. An objective classification method for Hess and Berezowsky Grosswetterlagen over Europe. Theor. Appl. Climatol. 2007, 88, 17-42. [CrossRef]

38. Hess, P.; Brezowsky, H. Katalog der Grosswetterlagen Europas 1881-1976. 3. Verbesserte und ergänzte Auflage. Berichte des Deutschen Wetterdienstes 1977, 113, 1-140.

39. Gerstengarbe, F.W.; Werner, P.C. Katalog der Großwetterlagen Europas (1881-2004) nach Paul Hess und Helmuth Brezowsky, 6th ed.; Selbstverlag des Deutschen Wetterdienstes: Potsdam, Germany, 2005.

40. Khokhlov, V.; Umanska, O. European Atmospheric Circulation Classifications. J. Geogr. Environ. Earth Sci. Int. 2018, 16, 1-8. [CrossRef]

41. Bardossy, A.; Caspary, H.J. Detection of climate change in Europe by analyzing European atmospheric circulation patterns from 1881 to 1989. Theor. Appl. Climatol. 1990, 42, 155-167. [CrossRef]

42. Kaszewski, B.M.; Filipiuk, E. Variability of atmospheric circulation in Central Europe in the summer season 1881-1998 (on the basis of the Hess-Brezowsky classification). Meteorol. Z. 2003, 12, 123-130. [CrossRef]

43. Keevallik, S.; Post, P.; Tuulik, J. European circulation patterns and meteorological situation in Estonia. Theor. Appl. Climatol. 1999, 63, 117-127. [CrossRef]

44. Kyselý, J.; Domonkos, P. Recent increase in persistence of atmospheric circulation over Europe: Comparison with long-term variations since 1881. Int. J. Climatol. 2006, 26, 461-483. [CrossRef]

45. Ustrnul, Z. Spatial differentiation of air temperature in Poland using circulation types and GIS. Int. J. Climatol. 2006, 26, 1529-1546. [CrossRef]

46. Ustrnul, Z.; Wypych, A.; Winkler, J.A.; Czekierda, D. Late spring freezes in Poland in relation to atmospheric circulation. Quaest. Geogr. 2014, 33, 165-172. [CrossRef]

47. Bartoszek, K.; Skiba, D. Circulation types classification and for hourly precipitation events in Lublin (East Poland). Open Geosci. 2016, 8, 214-230. [CrossRef]

48. Kossowski, J. Zmienność z dnia na dzień maksymalnej i minimalnej temperatury powietrza. Ann. UMCS 1970, $25,206-213$.

49. Bigg, G.R.; Wise, S.M.; Hanna, E.; Mansell, D.; Bryant, R.G.; Howard, A. Synoptic climatology of cold air drainage in the Derwent Valley, Peak District, UK. Meteorol. Appl. 2014, 21, 161-170. [CrossRef]

50. Piskala, V.; Huth, R. Asymmetry of day-to-day temperature changes and its causes. Theor. Appl. Climatol. 2020, 140, 683-690. [CrossRef]

51. Kyselỳ, J. Influence of the persistence of circulation patterns on warm and cold temperature anomalies in Europe: Analysis over the 20th century. Glob. Planet. Change 2008, 62, 147-163. [CrossRef]

52. Kuziemska, D. Zróżnicowanie temperatury powietrza na obszarze Polski a typy cyrkulacji atmosferycznej nad Europa Środkowa. Przegl. Geofiz. 1987, 32, 277-287.

53. Szwejkowski, Z.; Dragańska, E.; Grabowska, K. Następstwo elementów pogodowych w Polsce północno-wschodniej w latach 1951-2000. Przeglad Naukowy IiKŚ SGGW XV 2006, 1, 123-136. 
54. Tomczyk, A.M. Impact of atmospheric circulation on the occurrence of hot nights in Central Europe. Atmosphere 2018, 9, 474. [CrossRef]

55. Philipp, A.; Beck, C.; Huth, R.; Jacobeit, J. Development and comparison of circulation type classification using the COST733 dataset and software. Int. J. Climatol. 2014, 36, 2671-2809. [CrossRef]

56. Tang, Q.; Leng, G. Damped summer warming accompanied with cloud cover increase over Eurasia from 1982 to 2009. Environ. Res. Lett. 2012, 7, 014004. [CrossRef] 